\title{
A REVIEW OF THE FISH INTRODUCTIONS IN BULGARIAN FRESHWATERS
}

\author{
Eliza UZUNOVA* and Sonja ZLATANOVA
}

\author{
Division of General and Applied Hydrobiology, Faculty of Biology, Sofia University, Sofia, Bulgaria
}

Uzunova E., Zlatanova S. 2007. A review of the fish introductions in Bulgarian freshwaters. Acta Ichthyol. Piscat. 37 (1): 55-61.

\begin{abstract}
Background. Fish introductions have been a common tool to increase efficiency of utilization of water bodies and diversification of aquaculture production. As a result of increased interest in aquaculture and recreational fishing, throughout the past 70 years, the number of non-native fishes in Bulgaria has dramatically increased. This paper reviews the history, current state, and tendencies of the fish introductions in Bulgarian freshwaters. Materials and Methods. The statistical data about introductions and aquaculture production were provided by the National Agency Fisheries and Aquaculture (Ministry of Agriculture and Forestry). A part of the data for restocking activities was provided by Bulgarian Union of Hunters and Fishermen. The taxonomy of freshwater fishes was based on the review of Eschmeyer (2006).

Results. At present, twenty-six exotic species have been intentionally or unintentionally introduced in Bulgarian inland waters. They represent $15 \%$ of Bulgarian's freshwater fish fauna and provide more than $60 \%$ of aquaculture production. The most abundant are exotic cyprinids (Cyprinidae) and salmonids (Salmonidae), constituting $22 \%$ and $18 \%$ of all introductions, respectively. The most intensive import of non-indigenous fishes, namely East Asian herbivorous carps (Cyprinidae), into Bulgaria occurred in the middle of the 1960s. Only twelve species have been naturalized. Two of them (Lepomis gibbosus and Perccottus glenii) are considered invasive. Along with these fish introductions, parasites, bacterial and viral pathogens were imported.

Conclusions. The results of different fish introductions into Bulgarian freshwaters are controversial. Along with the positive influence on the aquaculture development, some extremely negative consequences, such as introduction of pathogens and spread of invasive species were observed. New introductions of fish species should not be made without scientific analyses evaluating the potential effects of introductions. Research, education, and strict control are the key tools of any effort to prevent the spread of the alien fish species.
\end{abstract}

Keywords: introductions, freshwater fish, Bulgaria, legislation

\section{INTRODUCTION}

While for millions of years, the climatic and geographic changes used to be the main driving force behind the species distribution, in the last centuries the great expansion of fish species can be mostly attributed to human activities. Especially numerous are the fish introductions in the fresh waters of Europe (Holčík 1991, Welcomme 1992, Cowx 1998). Significant changes were also observed in fish biodiversity in Bulgarian fresh waters during the last 50 years. Now, it is difficult to find a body of water without nonindigenous fish (Karapetkova et al. 1998).

The results of the introduction of alien species, although observed as increasing the utilization efficiency of water bodies and diversification of aquaculture production, are considered negative and they are comparable to the influence of over-fishing, habitat damage, and water pollution (Moyle et al. 1987, Allendorf 1991, Holčík 1991, Welcomme 1992, Cowx 1998, Witkowski 2002).
Unfortunately, in some cases, these consequences have a delayed and irreversible effect. It is considered that observed appearance of competitive relationships, transfer of indigenous parasites and/or inbreeding with native species, lead to decreasing in biodiversity and changes in the genetic structure of the local populations (Allendorf 1991, Evans and Willox 1991, Goodman 1991, Holčík 1991, Economidis et al. 2000, van Zyll de Jong et at. 2004). Elvira and Almodóvar (2001) have defined acclimatization of the exotic fishes in Spanish rivers as one of the most important negative factors affecting survivor of the native species. Even extinction of species from other taxonomic groups is sometimes related to exotic fish introduction (Denoel et al. 2005). Unfortunately, the negative results from the ecological point of view in some cases have been ignored due to the economic significance of these introductions.

This paper reviews the history, current state and tendencies of the fish introductions in Bulgarian freshwaters.

\footnotetext{
${ }^{*}$ Correspondence: Dr. Eliza Uzunova, Division of General and Applied Hydrobiology; Faculty of Biology; Sofia University; 8 Blvd. Dragan Tzankov, 1184 Sofia, Bulgaria, e-mail: e_uzunova@abv.bg
} 


\section{MATERIALS AND METHODS}

A total of 57 published sources, personal communications, and authors' own observations were used in the present study. The results were summarized in Table 1 and a graph (Fig. 1). The National Agency of Fisheries and Aquaculture (Ministry of Agriculture and Forestry) provided statistical data about aquaculture production. A part of the data for restocking activities was provided by the Bulgarian Union of Hunters and Fishermen. The taxonomy of freshwater fishes was based on the review of Eschmeyer (2006).

\section{RESULTS}

History, motives, and diversity of fish introductions in Bulgaria. The lack of sufficiently published data for Bulgaria decreased the reported number of fish introductions down to 7-8 (Holčík 1991, Elvira 2001). Information about the fish exotic for Bulgaria can be found in several ichthyological articles (Živkov et al. 2004, Vassilev and Pehlivanov 2003, Trichkova et al. unpublished). The updated list of the introduced fishes includes twenty-six species (Table 1). The most abundant are exotic cyprinids (Cyprinidae) and salmonids (Salmonidae), constituting $22 \%$ and $18 \%$ of all introductions, respectively. The aquaculture production, for 2004 (fish farms, cages, and fishery), from introduced species was about $70 \%$ of all fish production (Uzunova 2006). The situation in other countries in the region is the same, regarding numbers and diversity of the introduced fish species (Economidis et al. 2000, Witkowski 2002). Regarding the motives for fish introductions, there were no differences between Bulgaria and other European countries (Economidis et al. 2000, Elvira 2001, Elvira and Almodóvar 2001, Witkowski 2002). However, the choice has been mainly directed to species applicable to aquaculture, while the introductions for sport and recreational fisheries has been considerably less important.

The first fish introduction in Bulgaria was dated at the end of 18th century, when rainbow trout, Oncorhynchus mykiss (Walbaum, 1792), was imported (Grimaldi 1972, Welcomme 1988). However, regular imports of this species, mainly from other European countries, started in the 1930s when besides rainbow trout, brook trout, Salvelinus fontinalis (Mitchill, 1814) were also imported. These two species remain dominant in Bulgarian coldwater farming (Uzunova 2006).

The most intensive import of non-indigenous fishes, namely East Asian herbivorous carps (Cyprinidae), into Bulgaria was realized in the middle of the 1960s (Fig. 1). This activity was closely related to the state policy during this period, which was directed to the aquaculture industry. This was also a period of intensive hydro-construction, fish translocation, and restocking activity. The introduction of Chinese cyprinids significantly diversified the aquaculture production and at the same time changed the composition of fish species in almost all Bulgarian water bodies (Karapetkova et al. 1998). As soon as they were imported, easy artificial reproduction and a fast growth confirmed "herbivorous fishes" as leaders in Bulgarian warm-water aquaculture. The introductions of grass carp, Ctenopharyngodon idella (Valenciennes, 1844) and bighead carp, Aristichthys nobilis (Richardson, 1845), give an opportunity to apply so called "top-down control" for improving water quality. Black carp, Mylopharyngodon piceus (Richardson, 1846), is used as a tool in biological control of zebra mussel, Dreisena polymorpha (Pallas), population in Ovcharitza reservoir.

In 1977, three catostomid species (Catostomidae) were introduced and only several years later their successful naturalization was reported (Boâdžiev 1978, 1983, 1985). There is no current data about the status of their populations.

The most recent information about the new introductions concerns two species, North African catfish, Clarias gariepinus (Burchell, 1822), and barramundi, Lates calcarifer (Bloch, 1790)(Tanja Hubenova, pers. com.).

The number of introductions for sport fishing was limited and only few of them completed successful naturalization. Three species representing the family Coregonidae-Coregonus peled (Gmelin, 1788); C. albula (L.); and C. lavaretus (L.) - were naturalized in sever-
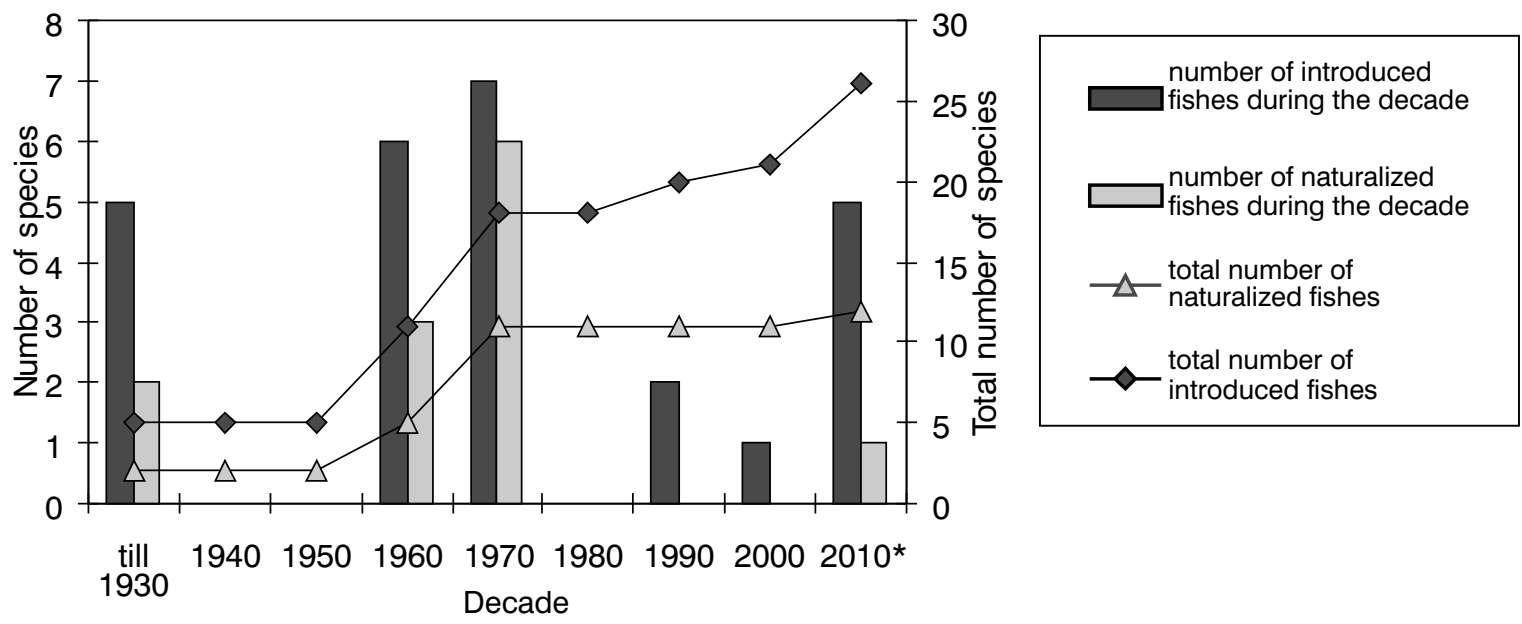

Fig. 1. Dynamics of the fish introduction and naturalization of exotic fishes into the Bulgarian inland waters during the decades $(*$ the latest data are of 2006) 
al very large mountain reservoirs, such as, Iskar and Dospat (Karapetkova et al. 1998). Conversely, ten years after the first introduction of landlocked salmon, Salmo salar sebago Girard, 1853, into several mid- to large reservoirs in Bulgaria, its current survival has not been confirmed.

By the end of the 1990s, in connection with different conservation projects and to fulfil CITES (Convention on International Trade in Endangered Species) recommendations concerning protection of sturgeon stocks, attempts have been made in Bulgaria to artificially propagate some of the native species intended for restocking in the Danube River (Zlatanova 2000). As known, some acipenserid species, such as Acipenser sturio L. and A. nudiventris Lovetsky, 1828 , seem to be extinct in the Danube River (Bacalbaşa-Dobrovici and Holčík 2000) or drastically decreased in number such as Huso huso (L.), Acipenser stellatus Pallas, 1771, A. gueldenstaedtii Brandt et Ratzeburg, 1833 (cf. Vassilev and Pehlivanov 2003, Bloesch et al. 2006). The existing native species have been supplemented by introduction of some exotic sturgeons. Acipenser baerii Brandt, 1869 and Polyodon spathula (Walbaum, 1792), mainly dui to their fast growth and high commercial value, are in process of acclimatization in some fish farms and reservoirs (Table 1) (Hubenova et al. 2004).

\section{DISCUSSION}

At the beginning of 20th century, Bulgaria's freshwater ichthyofauna was comparatively species rich (Kovačev 1922, Drenski 1945, 1948, 1951, Karapetkova et al. 1998, Trichkova et al. unpublished). During the last century, introduction and translocation of the large number of fish significantly changed the fish fauna composition in Bulgarian freshwater bodies. In fact, the exotic species are now dominant in number and biomass in the majority of rivers, lakes, and reservoirs. Exotic fishes get into natural waters by different ways. In most cases, it is impossible to put a physical barrier between natural fish populations and cultivated non-native fishes. Often between two groups, a non-stop bilateral exchange exists. This process is technically controllable, though in real life many small fishes and eggs enter in the natural waters, especially from hatching facilities and net cages (E. Uzunova, personal observation). The fish fauna composition in several Bulgarian reservoirs has formed as a result of regular stocking with exotic fishes (Živkov 1987, Grupcheva and Nedeva 1999). Within the period of 2004-2005, as a result of unusual heavy water flooding, a number of exotic species, cultivated in fully controllable conditions (cages, ponds, etc.) got into natural waters as those in rivers probably left the territory of Bulgaria (Tanja Hubenova, personal communications).

The wider tolerances to deterioration of water conditions or altered habitats of some exotic species give them advantages in survival. One of the indicative example is the shifting of the native salmonid species, brown trout (Salmo trutta $\mathrm{m}$. fario L.), by rainbow trout and brook trout in a number mountain lakes and rivers. Exotic salmonids can be found even in glacial lakes in Bulgaria (Karapetkova et al. 1998, Raikova-Petrova 2000). This is the result from brown trout over-fishing and long-lasting restocking with the exotic salmonid species, as well (Dikov et al. 1994). Actually, some authors believe that $S$. trutta m. fario replaced a native species, S. macedonicus (Karaman, 1924), in the past (Trichkova et al. unpublished).

Regarding the fish composition, a similar situation exists in middle-lower river stretches. For example, in the Mesta River, in the beginning of the last century, 23 fish species were established (Šiškov 1939). At present, seven native fishes are extinct and five exotic species are found (Apostolos 2005). The same tendency is observed in middle stretch of the Iskar River (Raikova-Petrova et al. 2004). However, possible impact of introduced fishes in Bulgaria on the native fish biodiversity reduction is still unknown.

Actually, in Bulgarian freshwater bodies, only a few introduced species have succeeded in their naturalization. Whitefishes (Coregonus lavaretus, C. albula, and C. peled) have successfully adapted to the conditions of the larger and deeper upland Bulgarian reservoirs. Though there is no published data about natural reproduction of the brook trout, its inclusion in this group is rather probable. The channel catfish, Ictalurus punctatus (Rafinesque, 1818), and buffalo fishes of the genus Ictiobus (Catostomidae) are also considered as naturalized. Unfortunately, some undesirable and quickly spreading fishes such as stone moroko, Pseudorasbora parva (Temminck et Schlegel, 1846) and pumpkinseed, Lepomis gibbosus (L.) have also joined this group (Drenski 1923, Marinov 1979, Wildekamp et al. 1997, Şaşi and Balik 2003). This group could be enlarged by one of the most recent exotic fish species recorded in Bulgaria, Perccottus glenii Dybowski, 1877 (cf. Jurajda et al. 2006). It can be predicted that this species will be able to establish a stable population in the near future. Unfortunately, an investigation recorded a negative impact of this fish on the native fish fauna (Reshetnikov 2003). On the other hand, some introductions, due to different ecological, biological, and economical factors seem to have failed. For instance, only isolated specimens could be found from, introduced in the past, Mozambique tilapia, Oreochromis mossambicus (Peters, 1852) and grayling, Thymallus thymallus (L.). The main reasons for that were unsuitable conditions in the recipient body of water or the small number of the introduced individuals.

One of the most negative effects of fish introductions in Bulgaria is the wide spread of numerous exotic bacterial, viral, and parasitic diseases. After the introduction of East Asian herbivorous carps, more than twelve parasites were transferred. It is considered that some of them, Cryptobia branchialis, Eimeria sinensis, Myxobolus pavlovskii, Trichodina nobilis, Tripartiella pulbosa, Dactylogyrus aristichthys, D. nobilis, D. achmerowi, and Bothriocephalus acheilognathi are pathogenic (Margaritov and Nguen 1984, Margaritov 1984a, b). Soon after the introduction of those pathogens, common carp, 
$\frac{\overline{0}}{\frac{0}{0}}$

界
苇

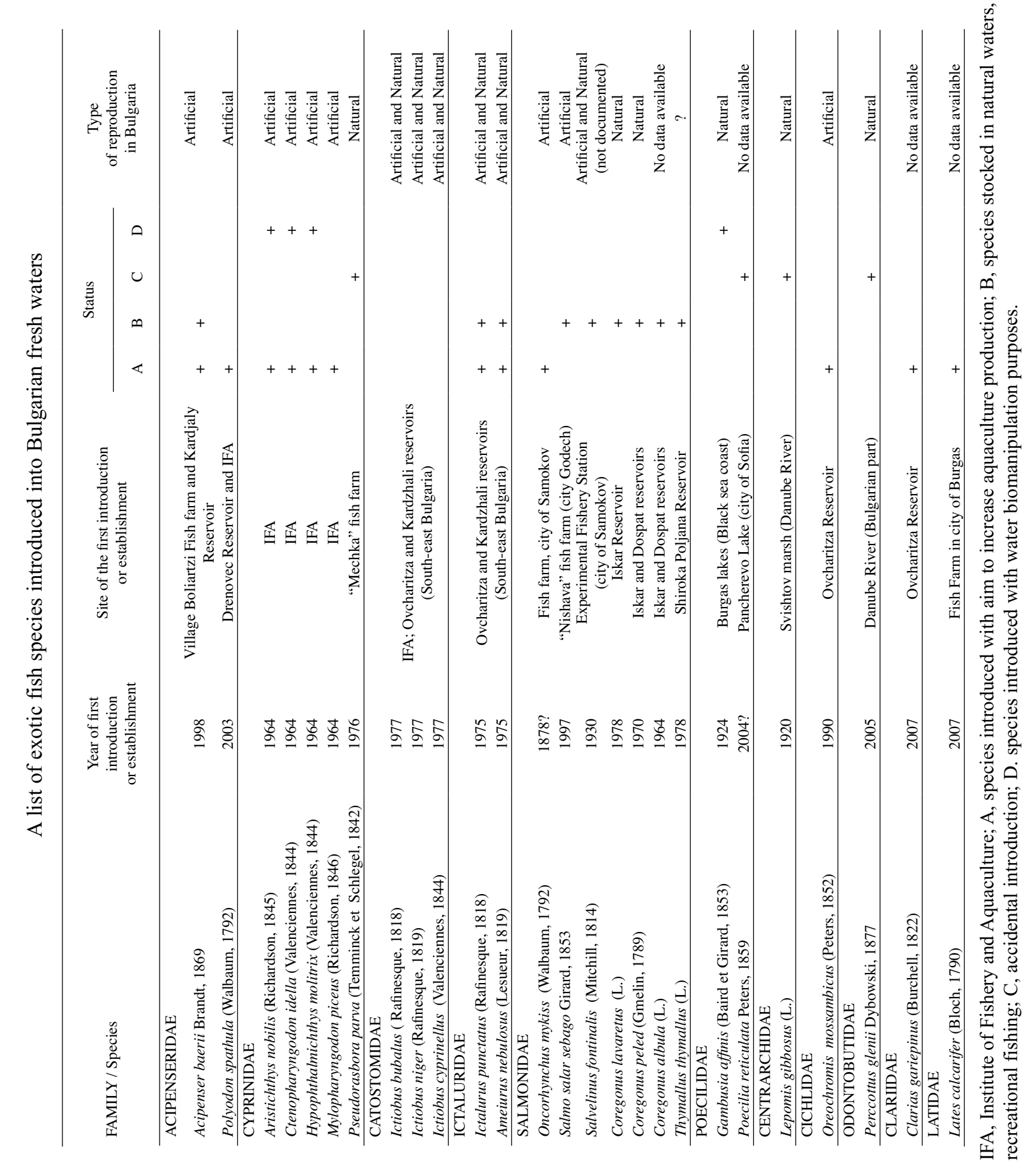


Cyprinus carpio L. was also infected. With the introduction of channel catfish, Bulgarian parasite fauna was enriched with a new species, Ambiphrya ameuri (cf. Margaritov 1987, 1992).

The majority of bacterial and viral pathogens were imported into Bulgaria by introduced fish species. Some, such as, infectious pancreatic necrosis (IPN), viral hemorrhagic septicaemia (VHS), renibacteriosis, and enteric redmouth disease, caused significant losses in aquaculture (Chikova and Ilieva 2004, Chikova and Kolarova unpublished). It was found that the newly introduced fish, Polyodon spathula was infected with bacterial agent Aeromonas hydrophila (cf. Chikova 2006). Some of the pathogens were established in "wild" fish, inhabiting an area close to the infected fish farm (Čikova et al. 2004).

Possible problems related to the import of aquarium fish species must be mentioned, as well. Although legally defined and controlled, in practice, these fishes are possible carriers of different pathogens (Borisov et al. unpublished).

Legislative frames and possible control measures of the exotic fish introduction in Bulgaria. The legal background for introduction of exotic species in Bulgaria is as follows: 1) The Biodiversity Act (State Gazette N 77/09.09.2002); 2) Ordinance No 4/07.2003, on conditions and terms to issue licenses to introduce exotic, reintroduce local animal and plant species in the wild. The National Biodiversity Council decides about each particular introduction; 3) Ordinance No 27/02.2006 (State Gazette N 23/2006) about measures to prevent, limit and liquidate some contagious fish diseases.

In correspondence with the Food and Agriculture Organization (FAO) and European Inland and Fisheries Advisory Commission (EIFAC) Code of Practice about Introductions of Non-indigenous species and World Conservation Union (IUCN) guidelines for the prevention of the biodiversity loss (Anonymous 1995, 1997, 2000), Bulgarian scientists share the view that introductions of new species must be limited. Along these lines, aquaculture production must be increased and diversified based on local species with valuable qualities such as pike-perch, Sander lucioperca (L.); European perch, Perca fluviatilis L.; Northern pike, Esox lucius L.; wells catfish, Silurus glanis L., and others. In order to prevent negative ecological consequences such as genetic interactions between cultured and native fish populations, stocking sterile specimens of domesticated hatchery fish have been initiated in Bulgaria. The first attempt was made with triploidization of brook trout, Salvelinus fontinalis because its widespread use for restocking in Bulgarian high mountain lakes and rivers (Uzunova 2001). The relevant research as well as education of the public about the potential risks of fish introductions is essential component of the measures to prevent uncontrolled spread of alien fish species.

\section{CONCLUSION}

The results of different fish introductions into Bulgarian freshwaters are controversial. Along with the positive influence on the aquaculture development $(60 \%$ of the aquaculture production is provided by exotic fishes), some extremely negative consequences, such as introduction of pathogens and spread of invasive species (Lepomis gibbosus and Perccottus glenii) were observed. In spite of significant number of the introduced fishes in Bulgaria, only twelve succeed in naturalization.

New introductions of fishes should not be made without scientific analyses, evaluating the potential effects of introductions. Research, education, and strict control are the key tools of any effort to prevent the spread of the alien fish species and to mitigate the negative impacts of the already introduced species.

\section{ACKNOWLEDGEMENTS}

We thank Edward Currie (Defra, UK) for kindly checking the English of the manuscript. Two anonymous referees provided useful comments on the original manuscript.

\section{REFERENCES}

Allendorf F. 1991. Ecological and genetic effects of fish introductions: synthesis and recommendations. Canadian Journal Fisheries and Aquatic Sciences 48: 178-181.

Anonymous 1995. Precautionary approach to fisheries. Part 1. Guidelines on the precautionary approach to capture fisheries and introductions. FAO Fisheries Technical Paper 350/1.

Anonymous 1997. FAO Technical Guidelines for Responsible Fisheries, Aquaculture Development - 5. FAO, Rome.

Anonymous 2000. IUCN guidelines for the prevention of biodiversity loss caused by alien invasive species. IUCN, Gland, Switzerland.

Apostolos A. 2005. The ichthyofauna from the Bulgarian sector of the Mesta River. Acta Zoologica Bulgarica 57: 91-196.

Bacalbaşa-Dobrovici N., Holčík J. 2000. Distribution of Acipenser sturio L. 1758, in the Black Sea and its watershed. Boletín Instituto Español de Oceanografía 16: 1-254.

Bloesch J., Jones T., Reinartz R., Striebel B., Holcik J., Kynard B., Siciu R., Williot P. (eds.) 2006. Action Plan for the conservation of sturgeons (Acipenseridae) in the Danube River Basin. Nature and Environment No. 144. Council of Europe Publishing.

Boâdžiev A. [Boyadjiev A.] 1978. Bufaloto-perspektiven obekt za aklimatizaciâl. [Buffalo fish - a perspective species for acclimatization.] Rybno stopanstvo 4: 3-4. [In Bulgarian.].

Boâdžiev A. [Boyadjiev A.] 1983. P"rvi rezultati ot otgleždaneto na bufalo $\mathrm{v}$ našata strana. [First results from Buffalo fish propagation in our country.] Izvestiâ na instituta po sladkovodno ribov"dstvo, Plovdiv 17: 45 - 54. [In Bulgarian.].

Boâdžiev A. [Boyadjiev A.] 1985. Otgleždane na dvuletno i triletno buffalo $\mathrm{v}$ polikultura. [Rearing of two- and threeyears-old buffalo fish in polyculture]. Izvestiâ na instituta po sladkovodno ribov"dstvo, Plovdiv 18: 23-43. [In Bulgarian.]

Chikova V. 2006. Case of aeromonosis in paddlefish. XI Congress of Bulgarian Microbiologists, 5-7 October, Varna, Bulgaria.

Chikova V., Ilieva D. 2004. Detection of infectious pancreatic necrosis (IPN) virus in rainbow trout in Bulgaria. Bulgarian Journal of Veterinary Medicine 7: 129-135. 
Čikova V. [Chikova V.], Uzunova E., Rozdina D. 2004. PCR-podhodnpri diagnostikata na červena usta pri p"st"rvovite ribil. [PCR approach in diagnostic of redmouth disease in salmonid fish.] Životnov"dni nauki 41: 81-84. [In Bulgarian.]

Cowx I.G. (ed.) 1998. Stocking and introduction of fish. Fishing News Books, Oxford.

Denoel M., Dzukic G., Kalezic M.L. 2005. Effects of widespread fish introductions on paedomorphic Newts in Europe. Conservation Biology 19: 162-170.

Dikov T., Jankov J., Jocev S. 1994. Fish stocks in the rivers of Bulgaria. Polskie Archiwum Hydrobiologii 41: 377-391.

Drenski P. 1923. Eupomotis gibbous L. edin nov vid v Svišovskoto ezero. [Eupomotis gibbous L. one new fishes in the Lake Svishtovsko.] Svedeniâ po zemedelieto 11: 6-7. [In Bulgarian.].

Drenski P. 1945. Zoogeografska skica na B"lgariâ. [Zoogeographic outline of Bulgaria.] Godišnik na Sofijskiâ Universitet 42: 109-161. [In Bulgarian.].

Drenski P. 1948. S"stav i razprostranenie na ribite v B"lgariâ. [Composition and distribution of fishes in Bulgaria.] Godišnik na Sofijskiâ Universitet 44: 66-67. [In Bulgarian.]

Drenski P. 1951. Ribite v B"lgariâ. [Fishes in Bulgaria.] B"lgarska Akademiâ na Naukite, Sofiâ [In Bulgarian.].

Economidis P.S., Dimitriou E., Pagoni R., Michaloudi E., Natsis L. 2000. Introduced and translocated fish species in the inland waters of Greece. Fisheries Management and Ecology 7: 239-250.

Elvira B. 2001. Identification of non-native freshwater fishes established in Europe and assessment of their potential threats to the biological diversity. Council of Europe; Convention on the conservation of European wildlife and natural habitats; Standing Committee; 21st meeting; Strasbourg, 26-30 November 2001; available at: http://www.coe.int/t/e/cultural_co\%2Doperation/environment/nature_and_biological_div ersity/nature_protection/sc21_06e.pdf?L=E.

Elvira B., Almodóvar A. 2001. Freshwater fish in Spain: facts and figures at the beginning of the 21st century. Journal of Fish Biology 59 (Supp. A): 323-331.

Eschmeyer W.N. 2006. Catalog of fishes. On-line version. Updated November 7, 2006 http://www.calacademy.org/research/ichthyology/catalog.

Evans D.O., Willox C.C. 1991. Loss of exploited indigenous population of lake trout, Salvelinus namaycush, by stocking of non-native stocks. Canadian Journal Fisheries and Aquatic Sciences 48 (Suppl. 1): 134-147.

Goodman B. 1991. Keeping anglers happy has a price: Ecological and genetic effects of stocking fish. BioScience 41: 294-299.

Grimaldi E. 1972. Lago Maggiore: Effects of exploitation and introductions on the salmonid community. Journal of the fisheries Research Board of Canada 29: 777-785.

Grupcheva G.I., Nedeva I.L. 1999. Ichthyofauna of the Zrebchevo reservoir (Bulgaria). Acta Zoologica Bulgarica 51: 53-55.

Holčík J. 1991. Fish introductions in Europe with particular reference to its central and eastern part. Canadian Journal Fisheries and Aquatic Sciences 48 (Suppl. 1): 13-23.

Hubenova T., Zaikov A., Karanikolov J., Grozev G. 2004. $\mathrm{P}^{\prime \prime}$ rvi rezultati ot otglejdaneto $\mathrm{V}$ B"lgariâ na veslonos (Polyodon spathula, Walbaum, 1792) do ukrepnal stadij.
[First study on paddlefish (Polyodon spathula, Walbaum, 1792) rearing in Bulgaria up to the fingerling size.] Životv"dni nauki 41: 36-39. [In Bulgarian.].

Jurajda P., Vassilev M., Polačik M., Trichkova T. 2006. A first record of Perccottus glenii (Perciformes: Odontobutidae) in the Danube River in Bulgaria. Acta Zoologica Bulgarica 58: 279-282.

Karapetkova M., Živkov M. 1995. Ribite v B"lgariâ. [Fishes in Bulgaria.] Izdalelstvo Geâ-Libris, Sofiâ. [In Bulgarian.]

Karapetkova M., Zivkov M., Alexandrova-Kolemanova K. 1998. The freshwater fishes of Bulgaria. Pp. 375-393. In: Meine C. (ed.) Bulgaria's biological diversity: Conservation status and needs assessment. Pensoft Publishers, Sofia.

Kovačev V.T. [Kovachev V.T.] 1922. Sladkovodnata ihtiologična fauna na B"lgariâ. [Freshwater ichthyofauna of Bulgaria.] Arhiv na Ministerstvo na zemedelieto i d"ržavnite imoti 3: 127-128. [In Bulgarian.].

Margaritov N. 1984a. Dactylogyrus achmerowi Gussev, 1955 nov vid za b"lgarskata parazitofauna. [Dactylogyrus achmerowi Gussev, 1955 - a new species of the Bulgarian parasitofauna.] Godišnik na Sofijskiâ Universitet “sv. Kliment Ohridski" 78: 90-94. [In Bulgarian.].

Margaritov N. 1984b. Paraziti po bufalovite ribi: po golâmoustoto bufali (Ictiobus cyprinelus, Val.), černoto bufalo (Ictiobus niger, Val.) i po tehniâ hibrid (Ictiobus cyprinelus $\times$ Ictiobus niger) $\mathrm{v}$ B"lgariâ. [Parasites on Buffalo fish: on the bigmouth buffalo (Ictiobus cyprinelus, Val.), on the black buffalo (Ictiobus niger, Val.) and their hybrid (Ictiobus cyprinelus $\times$ Ictiobus niger) in fish ponds in Bulgaria]. Godišnik na Sofijskiâ Universitet "sv. Kliment Ohridski” 78: 95-102. [In Bulgarian.].

Margaritov N. 1987. Parasites in channel catfish, Ictalurus punctatus (Raf.) in fish ponds in Bulgaria. In: 2nd International Symposium of Ichthyoparasitology "Actual problems in fish parasitology", September 27-October 3, 1987, Tihany, Hungary.

Margaritov N. 1992. Parasites on the breeding stock of channel catfish under conditions of intensive breeding in Bulgaria. Annuale l'Universite de Sofia "St. Kliment Ohridski" (Livre 1-Zoology) 81: 54-59.

Margaritov N., Nguen V.T. 1984. Vidov s"stav na parazitnata fauna na zaribitelnaiâ material ot rastitelnoâdni ribi. [Species composition of parasite fauna on stocking material of herbivorous fishes.] Ribno stopanstvo 3: 19-21. [In Bulgarian.].

Marinov B. 1979. Pseudorasbora parva (Schlegel, 1848), (Pisces, Cyprinidae) - nov vid za B"lgariâ. [Pseudorasbora parva (Schlegel, 1848), (Pisces, Cyprinidae) - a new fish species for Bulgaria.] Hidrobiologiâ 8: 75-78. [In Bulgarian.].

Moyle P.B., Li H.W., Barton B. 1987. The Frankenstein effect: impact of introduced fishes on native fishes in North America. Pp. 415-426. In: Stroud R.H. (ed.) The role of fish culture in fishery management. American Fishery Society, Bethesda.

Raikova-Petrova G. 2000. The ichthyofauna in the glacial water of the Rila mountains. Pp. 75-79. In: Biodiversity and evolution of glacial water ecosystems in the Rila mountains. Academic Publishing House, Sofia.

Raikova-Petrova G., Hamwi N., Petrov I. 2004. Changes in the ichthyofauna of the middle stream of Iskar River (Bulgaria). Forest Science 3: 87-92. 
Reshetnikov A.N. 2003. The introduced fish rotan (Perccottus glenii), depresses populations of aquatic animals (macroinvertebrates, amphibians, and a fish). Hydrobiologia 510: 83-90.

Şaşi H., Balik S. 2003. The distribution of exotic fishes in Anatolia. Turkish Journal of Zoology 27: 319-322.

Šiškov G. [Shishkov G.] 1939. Ribite ot našite reki ot Egejskiâ bâsejn. [The fishes in our rivers of the Aegean watershed.] Ribarski prigled 4: 1-3. [In Bulgarian.].

Uzunova E. 2001. Survival, growth and maturation of triploid brook trout (Salvelinus fontinalis) induced by heat shock. Biotechnology and Biotechnology Equipment 18: 82-90.

Uzunova E. 2006. Role of the introduced freshwater fishes in Bulgaria: economical benefits and ecological consequences. Bulgarian Journal of Agriculture Science 12: 170-175.

van Zyll de Jong M.C., Gibson R.J., Cowx I.G. 2004. Impacts of stocking and introductions on freshwater fisheries of Newfoundland and Labrador, Canada. Fisheries Management and Ecology, 11: 183-193.

Vassilev M., Pehlivanov L. 2003. Structural changes of sturgeon catches in the Bulgarian Danube section. Acta Zoologica Bulgarica 56: 233-235.

Welcomme R.L. 1988. International introductions of inland aquatic species. FAO Fisheries Technical Paper 294.

Welcomme R.L. 1992. A history of international introductions of inland aquatic species. ICES Marine Science Symposium 194: 3-14.
Widekamp R.H., Van Neer W., Küçük F.Z., Ünlüsayin M. 1997. First record of the eastern Asiatic gobionid fish Pseudorasbora parva from the Asiatic part of Turkey. Journal of Fish Biology 51: 858-861.

Witkowski A. 2002. Introduction of fishes into Poland: benefaction or plague? Nature Conservation 59: 41-52.

Živkov M. 1987. Ichtyofauna and fish utilization of the Dospat reservoir. Hydrobiology 30: 15-22.

Živkov M., Prodanov K., Tričkova T. [Trichkova T.], Raikova-Petrova G., Ivanova P. 2004. Ribite v B"lgariâ proučenost, opazvine i ustojčivo izpolzvane. [Fishes in Bulgaria-research priorities, conservational and sustainable use.] Pp. 247-281. In: Petrova A. (ed.) S"vremeno s"stoânie na bioraznoobrazieto v B"lgariâ - problemi i prespectivi. [Current state of the Bulgarian biodiversity-problems and perspectives.] B"lgarska Bioplatforma, Sofiâ. [In Bulgarian.].

Zlatanova S. 2000. Sturgeon fishing and trade in Bulgaria. Pp. 71-82. In: Otterstad O. (ed.) Proceeding from Kavala work

Received: 17 April 2007

Accepted: 6 July 2007

Published electronically: 15 July 2007 